\title{
Fish assemblage structure in the Chishui River, a protected tributary of the Yangtze River
}

\author{
J. $\mathrm{Wu}^{(1,2,3)}$, J. Wang ${ }^{(1,3)}, \mathrm{Y} . \mathrm{He}^{(1)}, \mathrm{W} . \mathrm{CaO}^{(1,3)}$ \\ Received November 18, 2010 \\ Revised March 14, 2011 \\ Accepted March 16, 2011
}

Key-words: Chishui River, fish distribution, environmental variables, canonical correspondence analysis (CCA), fish conservation

\section{ABSTRACT}

This study aimed to characterize fish assemblage and evaluate environmental influence on fish distribution in the Chishui River, a protected tributary of the upper Yangtze River. Thirty-one sites regularly distributed in longitudinal profiles were sampled in April, 2007. Sixty-two fish species belonging to 3 orders, 8 families, and 52 genera were collected. Species richness and diversity significantly increased from upstream to downstream. Canonical correspondence analysis (CCA) highlighted five environmental variables (altitude, conductivity, dissolved oxygen, channel width and current velocity) significantly structuring fish assemblages in the Chishui River. Based on species distributions and fish-habitat relationships, conservation strategies were proposed for different reaches.

\section{RÉSUMÉ}

Structure des communautés piscicoles de la rivière Chishui, un affluent protégé du fleuve Yangtzé

Mots-clés:
rivière Chishui,
distribution
de poissons,
variables envi-
ronnementales,
analyse
canonique des
correspondances
(CCA),
conservation
piscicole

Mots-clés :

Cette étude caractérise les communautés de poissons et évalue l'influence environnementale sur la distribution piscicole dans la rivière Chishui, un affluent protégé du fleuve Yangtzé. Trente-et-un sites régulièrement répartis sur le profil longitudinal ont été échantillonnés en avril 2007. Soixante-six espèces de poissons appartenant à 3 ordres, 8 familles et 52 genres ont été collectées. La richesse et la diversité spécifique augmentent significativement de l'amont vers l'aval. L'analyse canonique des correspondances (CCA) identifie cinq variables environnementales (altitude, conductivité, oxygène dissous, largeur du lit et vitesse du courant), structurant significativement les communautés de poissons dans la rivière Chishui. À partir des distributions spécifiques et des relations habitat-poisson, des stratégies de conservation sont proposées pour les différents biefs.

(1) Institute of Hydrobiology, Chinese Academy of Sciences, 7th southern road of East Lake, Wuhan, Hubei Province, 430072, P.R. China, wangjw@ihb.ac.cn

(2) Graduate University of Chinese Academy of Sciences, Beijing, 100039, P.R. China

(3) Key Laboratory of biodiversity and conservation of aquatic organisms, Chinese Academy of Sciences, Wuhan, Hubei Province, 430072, P.R. China 


\section{INTRODUCTION}

Fish assemblage is an important element in aquatic ecosystem. It provides a good biological indication for the quality of freshwater ecosystems since it is sensitive to a broad range of stressors (Karr, 1981; Oberdorff et al., 2002). It has been widely reported that the distribution and abundance of fish species are strongly related to environmental factors (Tejerina-Garro et al., 1998; Brown, 2000). These factors include topographical characteristics (Platts, 1979), climate (Eaton and Scheller, 1996), hydrological regime (Poff and Allan, 1995), riparian land use (Lammert and Allan, 1999), and water physical-chemical variables such as dissolved oxygen and pH (Matthews and Hill, 1979). These abiotic parameters have short-term or long-term influences on the structure of fish assemblages (Gasith and Resh, 1999). Apart from abiotic factors, biotic factors such as predation and competition could also affect fish assemblages via direct and indirect mechanisms (Jackson et al., 2001).

Characterizing the factors that structure fish assemblages is useful for river management and fish preservation. Similar studies on fish-habitat relationships have been carried out in South America (e.g. Fialho et al., 2008), North America (e.g. Feyrer and Healey, 2003), Europe (e.g. Godinho et al., 2000) and Africa (e.g. Ibanez et al., 2007), but are still lacking for Asia (Shahnawaz et al., 2010), and especially for China rivers.

With at least 286 fish species and subspecies distributing in the main channel and its affiliated tributaries, the upper Yangtze River is considered as a biodiversity hot spot for fish conservation (He et al., 2011). In the past decades, fish resources decreased dramatically and endemic species faced continuous threats. Dams, overfishing, pollution, deforestation, land erosion and other human activities were considered as main threats to fish biodiversity (Fu et al., 2003). The National Nature Reserve for rare and endemic fishes of the upper Yangtze River (NNRYR) was established in 2005 to protect fish resources. The protection zone included $353 \mathrm{~km}$-long mainstream and some tributaries (the Chishui River; the river-mouth of the Minjiang River, the Tuojiang River, the Yuexi River, the Nanguang River, the Changning River and the Yongning River). Being the last undammed tributary of the upper Yangtze River, the Chishui River is an important part of the protection zone.

In this paper, we analysed the structure of fish assemblages in the Chishui River during April 2007. Our main objectives were: 1) to characterize the composition and spatial variation of fish assemblages, and 2) to identify the main environmental factors responsible for the variation in fish assemblages.

\section{MATERIALS AND METHODS}

\section{> STUDY AREA}

The Chishui River $\left(27^{\circ} 20^{\prime}-28^{\circ} 50^{\prime} \mathrm{N}, 104^{\circ} 45^{\prime}-106^{\circ} 51^{\prime} \mathrm{E}\right)$ is the right tributary of the upper Yangtze River basin. It originates from the Wumeng Mountains in Yunnan province and flows for $437 \mathrm{~km}$ before joining the Yangtze River in Hejiang County of Sichuan Province, southwest of China. The river can be divided into three reaches as follows. The upstream reach with a length of $224.7 \mathrm{~km}$ extends from the source to Maotai Town in Guizhou Province. The midstream reach with a length of $158 \mathrm{~km}$ ranges from Maotai Town to Chishui City in Guizhou Province. Finally, the downstream reach extends from Chishui City to Hejiang County with a length of $54.3 \mathrm{~km}$. The whole Chishui River was included in the study.

\section{$>$ SAMPLING}

Thirty-one sites (13 in the upstream, 11 in the midstream and 7 in the downstream reaches, respectively) were sampled in an upstream direction with two electrofishing pass (by wading in shallow areas and from a boat in deeper areas) (Table I, Figure 1). Each sampling was conducted along about 200-500 m reach in the river and usually contain all kinds habitats 
Table I

Locations and regional attributes of sampling sites in the Chishui River. Attribute: $M$ means the site is located in the mainstream and T means the tributary of the Chishui River.

Tableau I

Localisation et attribut régional des sites échantillonnés dans la rivière Chishui. Attribut: $M=l e$ site est sur le cours principal et $\mathrm{T}=$ le site est sur un affluent de la rivière Chishui.

\begin{tabular}{|c|c|c|c|c|c|c|}
\hline Site code & Site name & Latitude & Longitude & Altitude (m) & DM $(\mathrm{km})$ & Attribute \\
\hline 1 & YD & $27^{\circ} 37^{\prime} 36^{\prime \prime}$ & $105^{\circ} 01^{\prime} 45^{\prime \prime}$ & 1197 & 409.2 & $\mathrm{M}$ \\
\hline 2 & $\mathrm{DH}$ & $27^{\circ} 46^{\prime} 36^{\prime \prime}$ & $105^{\circ} 06^{\prime} 19^{\prime \prime}$ & 990 & 378.3 & $\mathrm{~T}$ \\
\hline 3 & PT & $27^{\circ} 41^{\prime} 38^{\prime \prime}$ & $105^{\circ} 17^{\prime} 57^{\prime \prime}$ & 909 & 349.4 & $\mathrm{~T}$ \\
\hline 4 & CY & $27^{\circ} 47^{\prime} 35^{\prime \prime}$ & $105^{\circ} 15^{\prime} 32^{\prime \prime}$ & 855 & 368.9 & $\mathrm{~T}$ \\
\hline 5 & $\mathrm{XT}$ & $27^{\circ} 42^{\prime} 59^{\prime \prime}$ & $105^{\circ} 18^{\prime} 46^{\prime \prime}$ & 913 & 346.4 & M \\
\hline 6 & SL & $27^{\circ} 45^{\prime} 11^{\prime \prime}$ & $105^{\circ} 21^{\prime} 39^{\prime \prime}$ & 672 & 339.2 & M \\
\hline 7 & XJ & $27^{\circ} 44^{\prime} 53^{\prime \prime}$ & $105^{\circ} 32^{\prime} 16^{\prime \prime}$ & 602 & 315.3 & M \\
\hline 8 & DX & $27^{\circ} 45^{\prime} 32^{\prime \prime}$ & $105^{\circ} 32^{\prime} 08^{\prime \prime}$ & 635 & 316.4 & $\mathrm{~T}$ \\
\hline 9 & $\mathrm{CZ}$ & $27^{\circ} 43^{\prime} 25^{\prime \prime}$ & $105^{\circ} 35^{\prime} 01^{\prime \prime}$ & 597 & 308.6 & M \\
\hline 10 & WT & $27^{\circ} 43^{\prime} 21^{\prime \prime}$ & $105^{\circ} 46^{\prime} 35^{\prime \prime}$ & 515 & 279.4 & M \\
\hline 11 & SS & $27^{\circ} 54^{\prime} 32^{\prime \prime}$ & $105^{\circ} 42^{\prime} 41^{\prime \prime}$ & 1008 & 304.1 & $\mathrm{~T}$ \\
\hline 12 & QC & $27^{\circ} 40^{\prime} 10^{\prime \prime}$ & $105^{\circ} 55^{\prime} 23^{\prime \prime}$ & 522 & 268.7 & $\mathrm{~T}$ \\
\hline 13 & $\mathrm{JC}$ & $27^{\circ} 46^{\prime} 50^{\prime \prime}$ & $106^{\circ} 03^{\prime} 45^{\prime \prime}$ & 485 & 244.1 & M \\
\hline 14 & MT & $27^{\circ} 50^{\prime} 24^{\prime \prime}$ & $106^{\circ} 21^{\prime} 10^{\prime \prime}$ & 403 & 209.8 & M \\
\hline 15 & $\mathrm{HM}$ & $28^{\circ} 12^{\prime} 25^{\prime \prime}$ & $106^{\circ} 18^{\prime} 53^{\prime \prime}$ & 382 & 180.1 & M \\
\hline 16 & EL & $28^{\circ} 10^{\prime} 22^{\prime \prime}$ & $106^{\circ} 25^{\prime} 03^{\prime \prime}$ & 312 & 160.0 & $\mathrm{~T}$ \\
\hline 17 & LH & $28^{\circ} 08^{\prime} 52^{\prime \prime}$ & $106^{\circ} 10^{\prime} 39^{\prime \prime}$ & 393 & 166.4 & M \\
\hline 18 & YA & $28^{\circ} 03^{\prime} 58^{\prime \prime}$ & $105^{\circ} 54^{\prime} 40^{\prime \prime}$ & 482 & 188.7 & $\mathrm{~T}$ \\
\hline 19 & TC & $28^{\circ} 16^{\prime} 44^{\prime \prime}$ & $105^{\circ} 59^{\prime} 33^{\prime \prime}$ & 276 & 120.9 & M \\
\hline 20 & YH & $28^{\circ} 22^{\prime} 05^{\prime \prime}$ & $105^{\circ} 55^{\prime} 53^{\prime \prime}$ & 262 & 108.0 & M \\
\hline 21 & HS & $28^{\circ} 27^{\prime} 18^{\prime \prime}$ & $105^{\circ} 57^{\prime} 58^{\prime \prime}$ & 246 & 95.5 & M \\
\hline 22 & BA & $28^{\circ} 28^{\prime} 26^{\prime \prime}$ & $105^{\circ} 49^{\prime} 13^{\prime \prime}$ & 229 & 78.5 & M \\
\hline 23 & $\mathrm{FX}$ & $28^{\circ} 31^{\prime} 01^{\prime \prime}$ & $105^{\circ} 44^{\prime} 20^{\prime \prime}$ & 220 & 68.2 & $\mathrm{~T}$ \\
\hline 24 & DT & $28^{\circ} 30^{\prime} 41^{\prime \prime}$ & $105^{\circ} 40^{\prime} 44^{\prime \prime}$ & 223 & 63.5 & M \\
\hline 25 & CS & $28^{\circ} 34^{\prime} 33^{\prime \prime}$ & $105^{\circ} 41^{\prime} 16^{\prime \prime}$ & 219 & 54.5 & M \\
\hline 26 & CW & $28^{\circ} 39^{\prime} 39^{\prime \prime}$ & $105^{\circ} 45^{\prime} 13^{\prime \prime}$ & 211 & 39.4 & M \\
\hline 27 & XS & $28^{\circ} 42^{\prime} 55^{\prime \prime}$ & $105^{\circ} 43^{\prime} 21^{\prime \prime}$ & 206 & 27.8 & M \\
\hline 28 & $M X$ & $28^{\circ} 47^{\prime} 11^{\prime \prime}$ & $105^{\circ} 46^{\prime} 35^{\prime \prime}$ & 209 & 14.4 & M \\
\hline 29 & $\mathrm{HK}$ & $28^{\circ} 48^{\prime} 10^{\prime \prime}$ & $105^{\circ} 50^{\prime} 39^{\prime \prime}$ & 198 & 0.0 & M \\
\hline 30 & GD & $28^{\circ} 33^{\prime} 18^{\prime \prime}$ & $106^{\circ} 05^{\prime} 04^{\prime \prime}$ & 259 & 66.1 & $\mathrm{~T}$ \\
\hline 31 & $\mathrm{CH}$ & $28^{\circ} 41^{\prime} 23^{\prime \prime}$ & $105^{\circ} 59^{\prime} 10^{\prime \prime}$ & 220 & 46.9 & $\mathrm{~T}$ \\
\hline
\end{tabular}

(riffles, runs and pools). All sampled fishes were fixed in buffered formaldehyde (7\%) and transported to the laboratory for counting and taxonomic determination $\mathrm{Wu}, 1989$; Chen, 1998; Chu et al., 1999; Yue, 2000). Fish data were expressed in a matrix as species abundance per hour by site.

Sixteen environmental factors were examined on each sampling site. Water temperature $\left(\mathrm{WT},{ }^{\circ} \mathrm{C}\right)$, dissolved oxygen (DO, $\left.\mathrm{mg} \cdot \mathrm{L}^{-1}\right), \mathrm{pH}$ and conductivity $\left(\mu \mathrm{S} \cdot \mathrm{cm}^{-1}\right)$ were recorded by a multi-parametric probe (WTW Multi 340i). Altitude $(\mathrm{m})$ was recorded by an altimeter (Garmin GPS-76). Current velocity (CV, $\left.\mathrm{m} \cdot \mathrm{s}^{-1}\right)$ was measured using a flow-meter (LJD-10). Average water depth (WD, m) was calculated using a depth sounder (S48-1X). Average channel width (CW, m) was calculated by Leica CRF900. Substratum was divided into four types as sand, silt, cobble and boulder. The proportion (\%) of each type was visually estimated. Distance from mouth (DM, $\mathrm{km}$ ) was obtained from a digitized 1:50 000 scale map. Average annual data of rainfall $(\mathrm{AR}, \mathrm{mm})$, temperature $\left(\mathrm{AT},{ }^{\circ} \mathrm{C}\right)$ and sunlight (AS, hours) were gathered from the weather station nearby. 


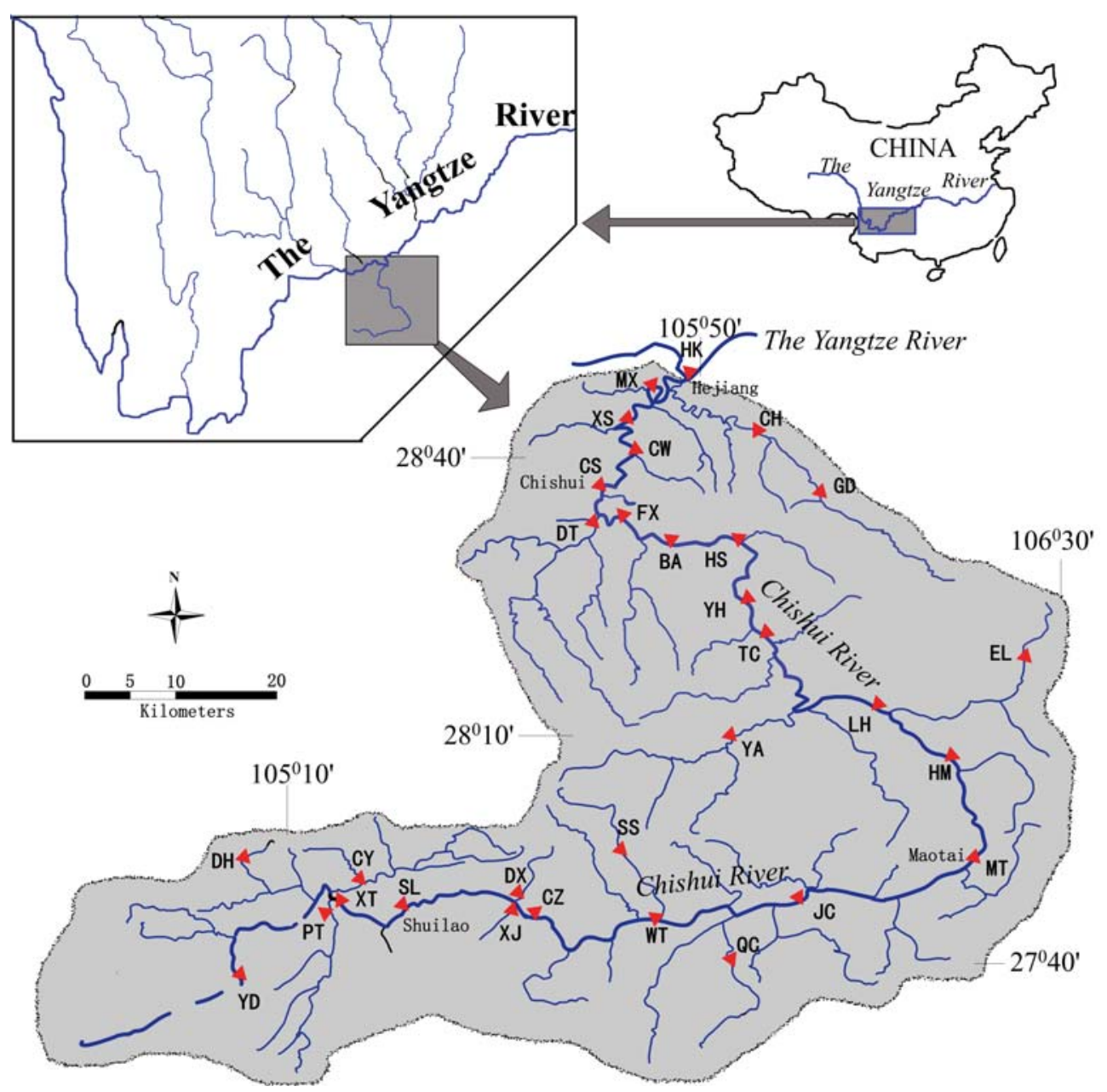

Figure 1

Sketch of 31 sampling sites (red triangles) in the Chishui River and its branch (blue line).

Figure 1

Localisation des 31 sites échantillonnés (triangles rouges) dans la rivière Chishui et ses affluents (ligne bleue).

\section{> DATA ANALYSIS}

Environmental and biological differences among the three reaches were tested using oneway analyses of variance (ANOVAs). These comparisons were carried out with Tukey's honestly significant difference (HSD) post hoc tests. In cases of persistent heteroscedasticity (results of Levene's test significant), we performed Games-Howell tests which do not assume equal variances between groups. All ANOVAs were made using SPSS statistical programs (version 13.0).

Canonical correspondence analysis (CCA) with Hill's scaling on inter-species distances was used to display the relationship between fish assemblage structure and the 16 environmental variables. According to the preliminary CCA, collinear environmental variables with high variance inflation factors (VIF $>20$ ) were eliminated from further analyses. Stepwise forward selection with Monte Carlo test (999 permutations, $P<0.05$ ) was used to select a minimum set of environmental variables that had significant and independent effects on fish distribution. Monte Carlo test (999 permutations, $P<0.05$ ) was also used to determine the significance of each analysis under the null hypothesis that no relationship between fish and environmental 
variables existed. Two tests were performed: one based on the first CCA ordination axis and the other based on all canonical axes together.

Fish data were logarithmically transformed $\left(\log _{10}(x+1)\right)$, environmental variables that did not meet the normality assumption (Shapiro-Wilk test, $P<0.05$ ) were transformed using natural logarithms. CCA analyses were performed using the software CANOCO for Windows 4.5 version (ter Braak and Smilauer, 2002).

\section{RESULTS}

\section{> FISH ASSEMBLAGES}

A total of 62 fish species, representing 52 genera, 8 families and 3 orders, were collected during the study period. Eighteen of them were endemic to the upper Yangtze River basin. Cypriniforms had the largest number of species (49 species), followed by Siluriforms (11 species) and Perciforms (2 species) (Table II). Cyprinidae was the most dominant family in species number, accounting for $66.1 \%$ of all species. Squalidus argentatus, Zacco platypus, Pseudobagrus truncates, Spinibarbus sinensis, Opsariichthys bidens and Hemibarbus maculatus were the most abundant species, accounting for $27.7 \%$ of all individuals captured during the sampling period. As shown in Table III, 5 species were common (occurrence $>75 \%$ ), 34 species were at a moderate common level (occurrence between $25 \%$ and $75 \%$ ) and 23 species were scarce (occurrence $<25 \%$ ). Eight species occurred exclusively in the upstream reach, 1 in the midstream reach and 10 in the downstream reach, respectively. The downstream reach had the highest species richness and diversity per site (31 species, 4.29 bit), followed by the midstream reach ( 25 species, 4.06 bit) and the upstream reach (19 species, 3.52 bit). However, there were no significant differences in abundance among the three reaches (Table III).

\section{> ENVIRONMENTAL GRADIENTS}

As shown in Table IV, environmental variables of the Chishui River displayed large variance along the upstream-downstream gradient. Altitude, channel width, water depth and distance from mouth varied significantly for the three reaches. Channel width and water depth increased with the decreasing altitude and distance from mouth. Water temperature in the upper reaches was relatively low (below $20^{\circ} \mathrm{C}$ ) and increased in a downstream direction, as well as conductivity. Dissolved oxygen was about $8 \mathrm{mg} \cdot \mathrm{L}^{-1}$ in the whole river and peaked in the midstream reach. The water $\mathrm{pH}$ was slightly alkaline and showed no significantly difference among the three reaches. The proportion of substratum types differed among three reaches. The upper sites were dominated by cobble and sand, with less than $10 \%$ silt. The midstream reach had the highest boulder percentages and moderate sand. Silt significantly increased in a downstream direction. The climate of Chishui basin was warm and humid, meteorological factor except for annual temperature exhibited no significant difference among the three reaches.

\section{> ENVIRONMENTAL INFLUENCES ON FISH DISTRIBUTION}

The large variance inflation factors (VIF $>20$ ) of the preliminary CCA suggested redundancy among cobble, silt and water depth, and these variables were subsequently excluded from the environmental data set. The forward selection procedure showed that altitude, conductivity, dissolved oxygen, channel width and current velocity were the environmental variables that accounted for significant $(P<0.05)$ portions of the total variance in fish species composition. CCA with these five environmental variables produced an ordination in which all canonical axes were significant $(P=0.001)$. The eigenvalues for the first two axes were 
Table II

Lists of 62 species, showing fish fauna and species code. Asterisks denote endemic species.

Liste des 62 espèces et codes des espèces. L'astérisque marque les espèces endémiques.

\begin{tabular}{|c|c|}
\hline Species name & Species code \\
\hline \multicolumn{2}{|l|}{ Cypriniforms } \\
\hline \multicolumn{2}{|l|}{ Cyprinidae } \\
\hline Zacco platypus (Temminck et Schlegel) & Z.pla \\
\hline Opsariichthys bidens Günther & O.bid \\
\hline Ctenopharyngodon idellus (Cuvier et Valenciennes) & C.ide \\
\hline Squaliobarbus curriculus (Richardson) & S.cur \\
\hline Pseudolaubuca sinensis Bleeker & P.sin \\
\hline Sinibrama taeniatus (Nichols)* & S.tae \\
\hline Ancherythroculter kurematsui (Kimura)* & A.kur \\
\hline Ancherythroculter nigrocauda Yih et Woo* & A.nig \\
\hline Hemiculterella sauvagei Warpachowski* & H.sau \\
\hline Hemiculter leucisculus (Basilewsky) & H.leu \\
\hline Hemiculter tchangi Fang* & H.tch \\
\hline Cultrichthys erythropterus (Basilewsky) & C.ery \\
\hline Culter alburnus Basilewsky & C.alb \\
\hline Culter mongolicus (Basilewsky) & C.mon \\
\hline Xenocypris davidi Bleeker & X.dav \\
\hline Pseudobrama simoni (Bleeker) & P.sim \\
\hline Hypophthalmichthys molitrix (Cuvier et Valenciennes) & H.mol \\
\hline Hemibarbus labeo (Pallas) & H.lab \\
\hline Hemibarbus maculatus Bleeker & H.mac \\
\hline Pseudorasbora parva (Temminck et Schlegel) & P.par \\
\hline Sarcocheilichthys nigripinnis (Günther) & S.nig \\
\hline Squalidus argentatus (Sauvage et Dabry) & S.arg \\
\hline Rhinogobio typus Bleeker & R.typ \\
\hline Abbottina rivularis (Basilewsky) & A.riv \\
\hline Saurogobio dabryi Bleeker & S.dab \\
\hline Gobiobotia filifer (Garman) & G.fil \\
\hline Rhodeus ocellatus (Kner) & R.oce \\
\hline Spinibarbus sinensis (Bleeker) & S.sin \\
\hline Percocypris pingi (Tchang)* & P.pin \\
\hline Acrossocheilus monticolus (Günther)* & A.mon \\
\hline Acrossocheilus yunnanensis (Regan) & A.yun \\
\hline Onychostoma sima (Sauvage et Dabry) & O.sim \\
\hline Bangana rendahli (Kimura)* & B.ren \\
\hline Pseudogyrinocheilus procheilus (Sauvage et Dabry) & P.pro \\
\hline Sinocrossocheilus labiata Su, Yang et Cui* & S.lab \\
\hline Garra pingi (Tchang) & G.pin \\
\hline Schizothorax grahami (Regan)* & S.gra \\
\hline Schizothorax kozlovi Nikolsky* & S.koz \\
\hline Procypris rabaudi (Tchang)* & P.rab \\
\hline Cyprinus carpio Linnaeus & C.car \\
\hline Carassius auratus (Linnaeus) & C.aur \\
\hline \multicolumn{2}{|l|}{ Cobitidae } \\
\hline Paracobitis variegatus (Sauvage et Dabry) & P.var \\
\hline Paracobitis wujiangensis Ding et Deng* & P.wuj \\
\hline Oreias dabryi Sauvage* & O.dab \\
\hline Leptobotia elongata (Bleeker)* & L.elo \\
\hline Misgurnus anguillicaudatus (Cantor) & M.ang \\
\hline \multicolumn{2}{|l|}{ Homalopteridae } \\
\hline Lepturichthys fimbriata (Günther) & L.fim \\
\hline Sinogastromyzon sichangensis Chang* & S.sic \\
\hline Sinogastromyzon szechuanensis Fang* & S.sze \\
\hline
\end{tabular}


Table II

Continued.

Tableau II

Suite.

\begin{tabular}{|l|c|}
\hline Species name & Species code \\
\hline Siluriforms & \\
Bagridae & P.vac \\
Pelteobagrus vachelli (Richardson) & P.nit \\
Pelteobagrus nitidus (Sauvage et Dabry) & L.cra \\
Leiocassis crassilabris Günther & P.tru \\
Pseudobagrus truncatus (Regan) & P.ema \\
Pseudobagrus emarginatus (Regan) & P.pra \\
Pseudobagrus pratti (Günther) & M.mac \\
Mystus macropterus (Bleeker) & S.aso \\
Siluridae & S.mer \\
Silurus asotus Linnaeus & \\
Silurus meridionalis Chen & G.fok \\
Sisoridae & E.dav \\
Glyptothorax fokiensis (Rendahl) & \\
Euchiloglanis davidi (Sauvage)* & \\
Perciforms & S.chu \\
Serranidae & \\
Siniperca chuatsi (Basilewsky) & R.giu \\
Gobiidae & \\
Rhinogobius giurinus (Rutter) & \\
\hline
\end{tabular}

0.536 and 0.206 , respectively. The species-environment correlations for the first two axes were 0.942 and 0.940 , respectively. The first two axes accounted for $79.6 \%$ of the total variation explained by the environmental variables, of which $57.5 \%$ was contributed by the first axis and another $22.1 \%$ by the second. The intraset correlations between the environmental variables were examined to find out those variables most correlated with each of the axes. The first axis was correlated with altitude $(0.94)$ and channel width (0.65). The second axis was most correlated with conductivity $(-0.80)$, current velocity $(-0.75)$ and dissolved oxygen $(-0.63)$.

The CCA produced two biplots which showed the relationships between species, sites and environmental variables. From the site-environment biplot (Figure 2), all upstream sites had positive scores on axis 1 and clustered on the right half of the plot. Most sites in the midstream reach, except YA and MT, were clustered on the third quarter of the plot, with negative scores on axis 1 and axis 2. All sites in the lower reaches (except XS) were clustered in the second quarter of the plot. Three groups of species were discriminated by their location along the environmental gradient (Figure 3). The first group (e.g., Euchiloglanis davidi, Oreias dabryi, Schizothorax grahami, Schizothorax kozlovi and Acrossocheilus yunnanensis) with positive scores on axis 1 was representative of upstream areas. These species were associated with high altitude and narrow channel. The second group, with negative scores on axis 1 and axis 2, was constituted by species like Bangana rendahli. This group was abundant in the midstream reach with rapid flow, high conductivity and dissolved oxygen. The third group (e.g., Pseudobrama simoni, Pseudorasbora parva, Sarcocheilichthys nigripinnis, Rhodeus ocellatus and Silurus meridionalis) with negative scores on axis 1 and positive scores on axis 2 was representative of the downstream reach. This group was mainly related to wide channel, low altitude and low conductance.

\section{DISCUSSION}

\section{> FISH-HABITAT RELATIONSHIPS}

Significant relationships between environmental variables and fish assemblages were found in the Chishui River. Altitude was positively correlated with the first CCA axis and explained 
J. Wu et al.: Knowl. Managt. Aquatic Ecosyst. (2011) 400, 11

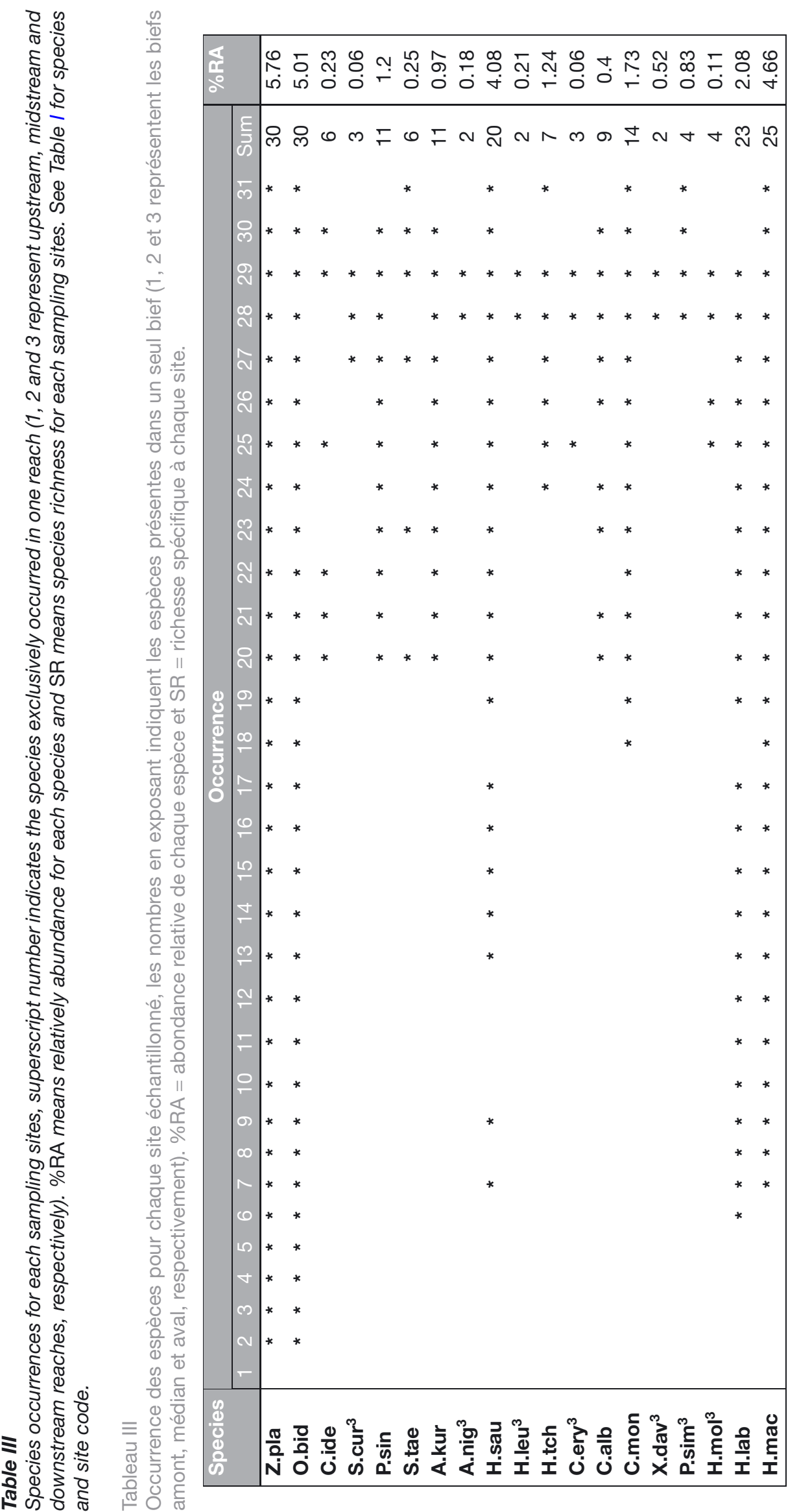




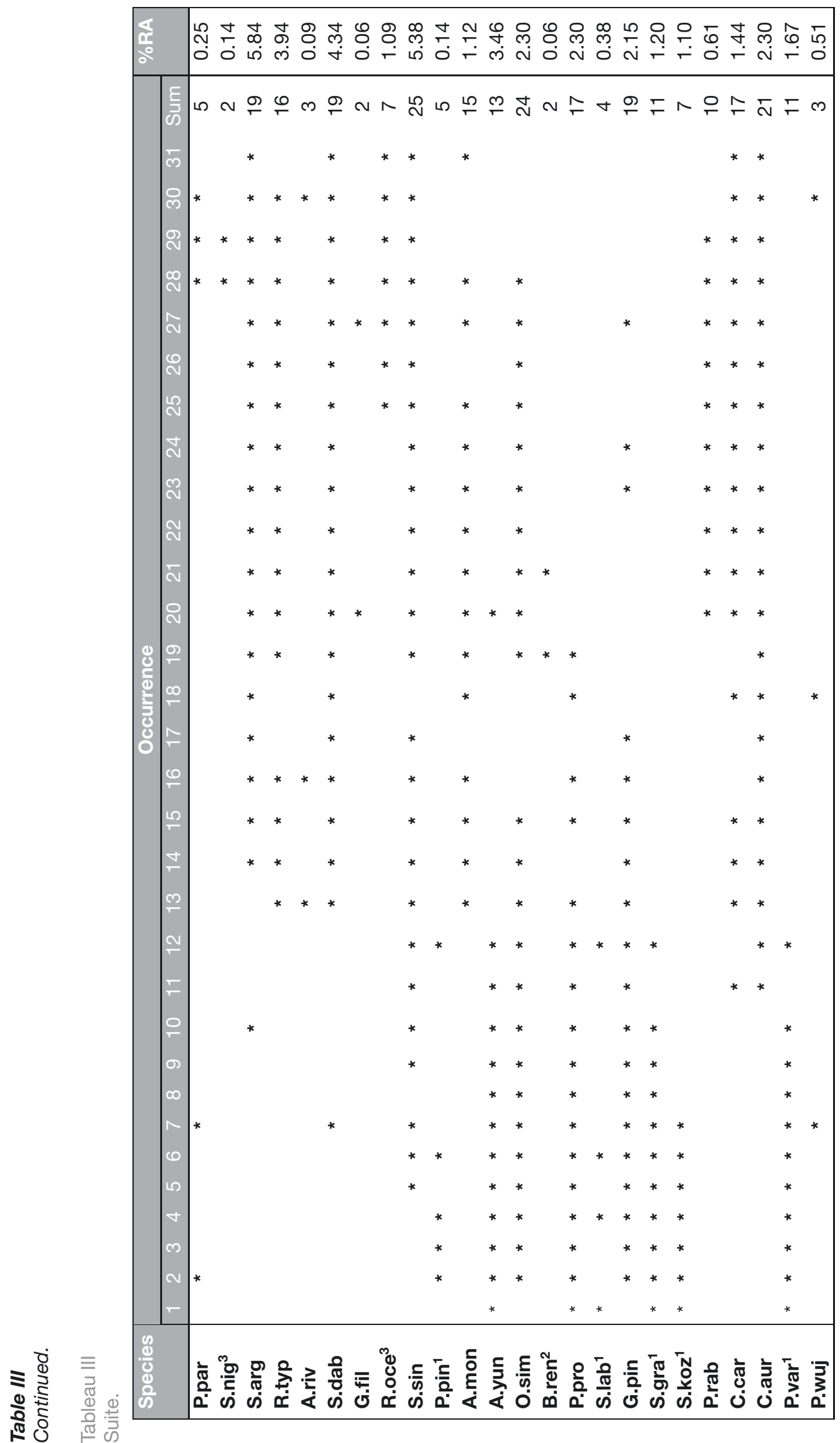




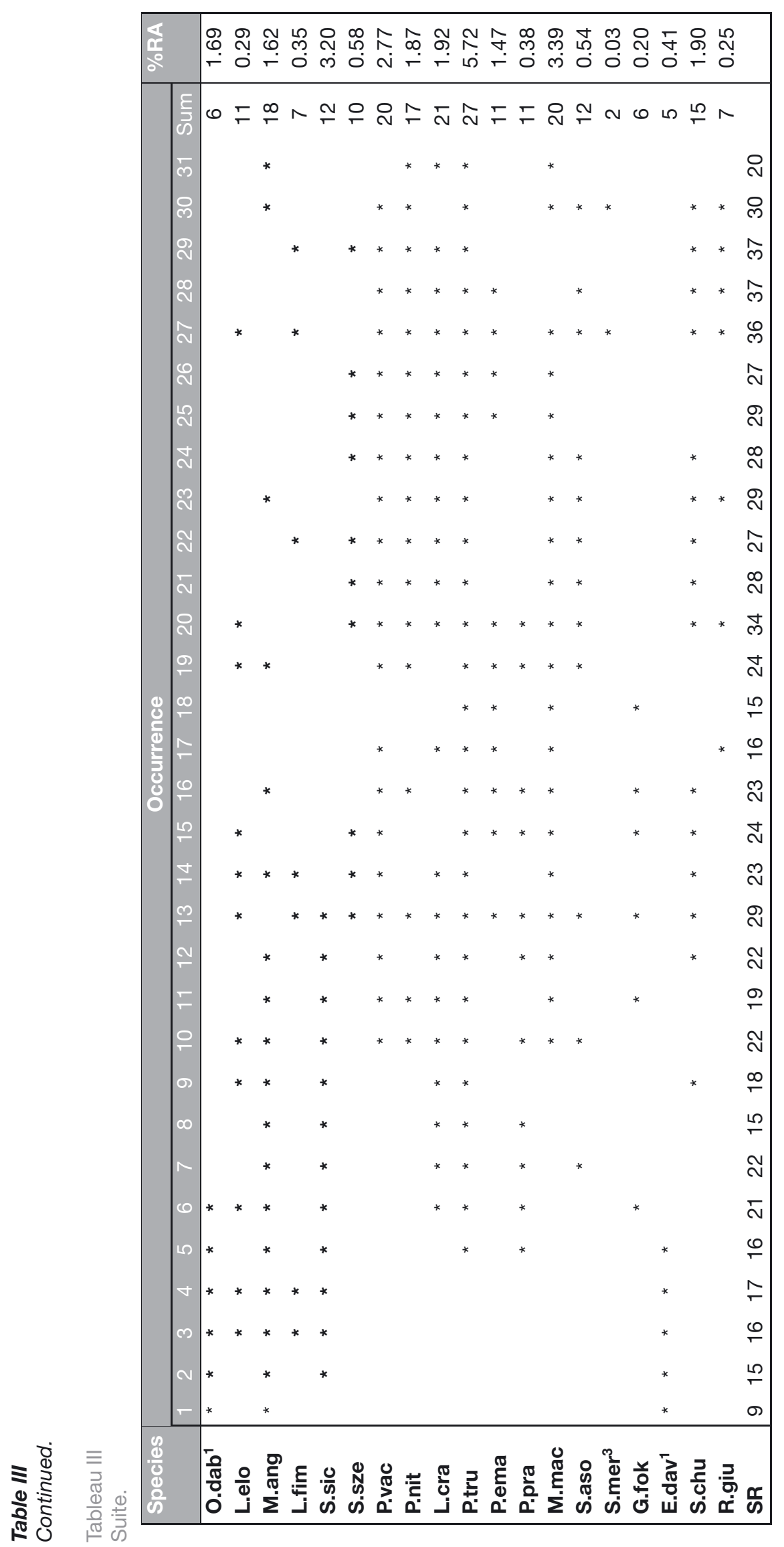




\section{Table IV}

Mean values and standard errors of the environmental and biological variables. Asterisks showing significant difference among reaches in ANOVA $(P<0.05)$.

\section{Tableau IV}

Valeur moyenne et erreur standard des variables environnementales et biologiques. Les astérisques signalent les différences significatives entre biefs dans une ANOVA $(P<0,05)$.

\begin{tabular}{|c|c|c|c|c|c|}
\hline & Upstream & Midstream & Downstream & F-ratio & P-valu \\
\hline \multicolumn{6}{|l|}{ Environmental data } \\
\hline Altitude $(\mathrm{m})^{\star}$ & $735.9 \pm 239.6$ & $302.5 \pm 88.7$ & $217.4 \pm 19.8$ & 29.30 & 0.000 \\
\hline Water temperature $\left({ }^{\circ} \mathrm{C}\right)^{*}$ & $15.4 \pm 2.9$ & $21.9 \pm 2.4$ & $23.2 \pm 1.7$ & 31.00 & 0.000 \\
\hline Conductivity $\left(\mu \mathrm{S} \cdot \mathrm{cm}^{-1}\right)^{*}$ & $365.5 \pm 28.6$ & $383.4 \pm 26.1$ & $290.4 \pm 38.4$ & 21.19 & 0.000 \\
\hline Dissolved oxygen $\left(\mathrm{mg} \cdot \mathrm{L}^{-1}\right)^{\star}$ & $8.20 \pm 0.26$ & $8.66 \pm 0.29$ & $7.67 \pm 0.94$ & 13.23 & 0.000 \\
\hline $\mathrm{pH}$ & & 0.28 & \pm 0.24 & 2.93 & 0.070 \\
\hline & .5 & 8.0 & 12 & 9.88 & 0.000 \\
\hline$\left.\cdot \mathrm{s}^{-1}\right)^{\star}$ & 0.91 & 0.28 & 0.7 & 12.84 & 0.000 \\
\hline & & & 2.6 & 19.83 & 0.000 \\
\hline & & & & 48.15 & 0.000 \\
\hline & & & 20. & 8.68 & 0.001 \\
\hline & 34.6 & $33.5 \pm 7.8$ & 20. & 10.05 & 0.001 \\
\hline & & $20.5 \pm 6.9$ & 20.5 & 14.68 & 0.000 \\
\hline & 317 & 123 & & 99.29 & 0.000 \\
\hline An & 15. & 17. & & 4.84 & 0.016 \\
\hline Anne & $1085.8 \pm 104.7$ & $1157.2 \pm 141.0$ & $1104.6 \pm 71.7$ & 1.69 & 0.203 \\
\hline Ann & 1154.1 & 1227.0 & 1214. & 1.02 & 0.375 \\
\hline \multicolumn{6}{|l|}{ Biologic } \\
\hline hness $^{*}$ & & & & 11.54 & 0.000 \\
\hline Abu & 190 & 218 & $24 c$ & 1.32 & 0.283 \\
\hline Shannon-Wiener Index & $3.52 \pm 0.53$ & $4.06 \pm 0.33$ & $4.29 \pm 0.34$ & 8.93 & 0.001 \\
\hline
\end{tabular}

significant directions of variance in species distributions. This result is similar to the one obtained by Edds (1993) who also noticed that altitude was the most important factor contributing to variation in fish assemblage in the Gandaki River. In the Chishui River, Schizothoracinae and Nemachilinae species which mainly appeared in the upper reaches at an altitude of $1000-1500 \mathrm{~m}$ are adapted to harsh environment of cold water and energy availability. On the other hand, some Cultrinae and Gobioninae species had a significant negative correlation with altitude and were mainly present in the lower sites. Hocutt and Stauffer (1975) suggested that species richness increases with both channel width and water depth. Large width and deep water lead to environmental stability and allow vertical and horizontal separation of microhabitat for fish species (Matthews, 1998). This phenomenon was in accordance with our findings. The downstream reach, characterized by wide channel and deep pools, was rich in phyto- and zooplanktonic community. Because of the increase in living space, habitat and food diversity, the number of fish species increased along an upstream-downstream gradient. Current velocity was another significant variable affecting the spatial pattern of fish species, which was negatively correlated with the second CCA axis. It turned out to be highest in the middle reaches, where the lotic species such as Bangana rendahli were typically abundant. In contrast, Culter mongolicus and Squalidus argentatus were abundant in the lower reaches, these lentic species commonly appear in lakes, ponds, pools and backwaters of large rivers in China (Chen, 1998). In addition, conductivity and dissolved oxygen survived in the forward selection procedure and acted as surrogates for axis 2 , these two factors were also observed and influenced the fish communities in a tropical river (Araujo et al., 2009). However, other expected factors such as substratum types and the meteorological factors were not significant in CCA, the former were due to their redundancy with altitude and were excluded by the variable selection procedure; the latter may be because the study area was relatively small that annual rainfall and sunlight exhibited no significant difference among the three reaches. 


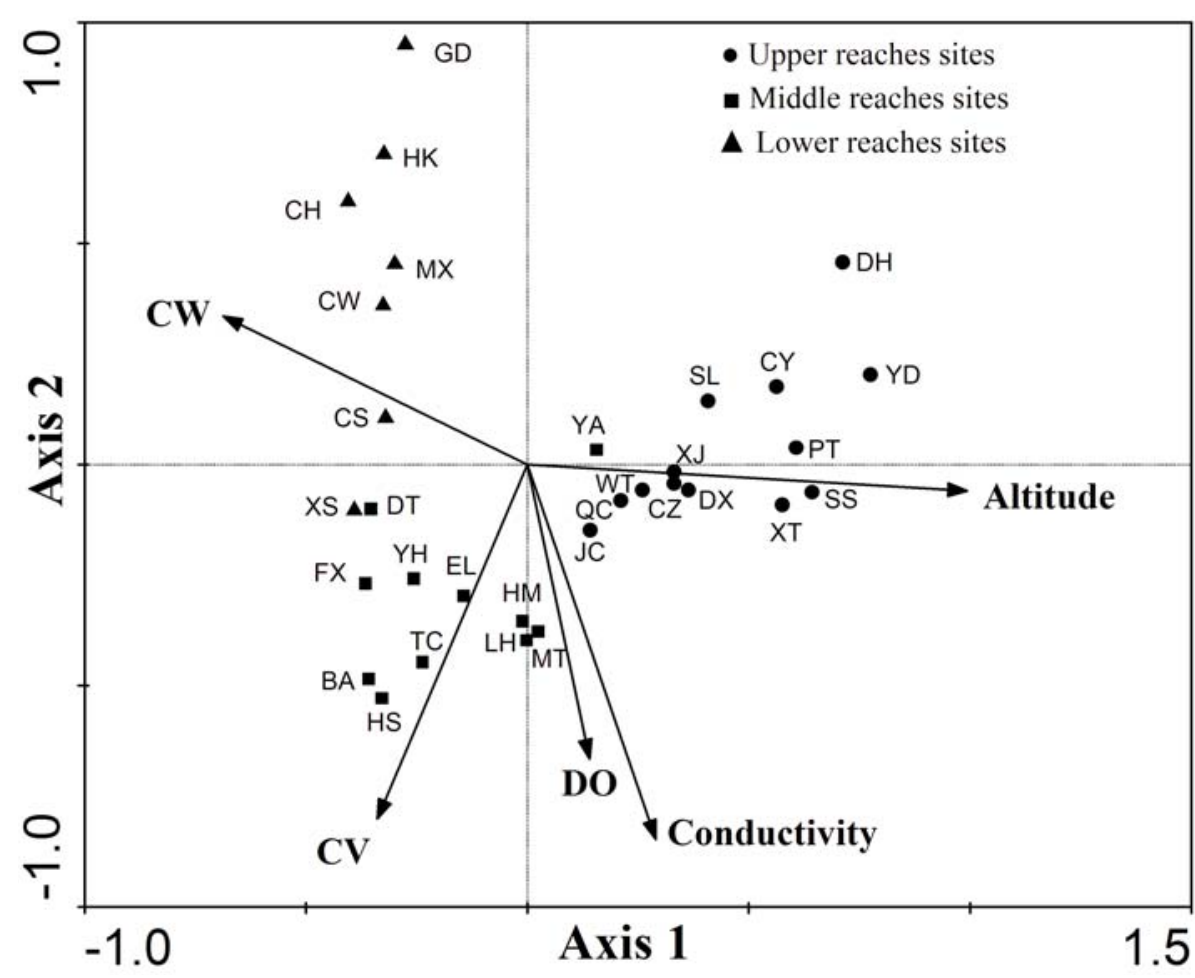

Figure 2

Canonical correspondence analysis ordination plots showing relationship between the distribution of sample sites and main environmental variables.

\section{Figure 2}

Graphique d'analyse canonique des correspondances montrant les relations entre la répartition des sites échantillonnés et les principales variables environnementales.

\section{> CONSERVATION IMPLICATIONS}

Our study showed that species composition varied significantly among the three reaches, thus, customized conservation strategies should be developed for different reaches.

The upstream reach is clearly discriminated from other reaches by the abundance of stenochoric species. High declivity affects fish movements, preventing recolonization of headwaters by species from lower reaches. Therefore, the upper reaches should be considered as an independent conservation unit to protect stenochoric species. These species adapted to low temperature and poor energy availability, typically exhibit slow growth, late maturity, and low fecundity. Thus, they are particularly vulnerable to fishing. Therefore, additional protection must be quickly made to protect this zone against fishing.

Although the midstream reach has moderate species richness and fewer narrow-distribution species, this zone is essential for fish spawning. Wu et al. (2010) reported that at least 34 species with different spawning strategies laid eggs throughout this region; some species laid drifting eggs in the middle channel while others produced adhesive eggs in backwater area near the bank. Unfortunately, this area is an important waterway route and suffers frequent channel regulations. Broadening and deepening the channel considerably homogenize the river form and slower water flow which will impact negatively the spawning habitats. Gravel mining which eliminates spawning areas for fish is another problem. Thus, more attention needs to be paid to canalization plans and gravel mining in this zone.

The downstream of the Chishui River supports the highest species richness. The fish composition in this area is similar to the contiguous mainstream of the Yangtze River; all species of this downstream reach also appear in the mainstream of the Yangtze River (Ding, 1994). 


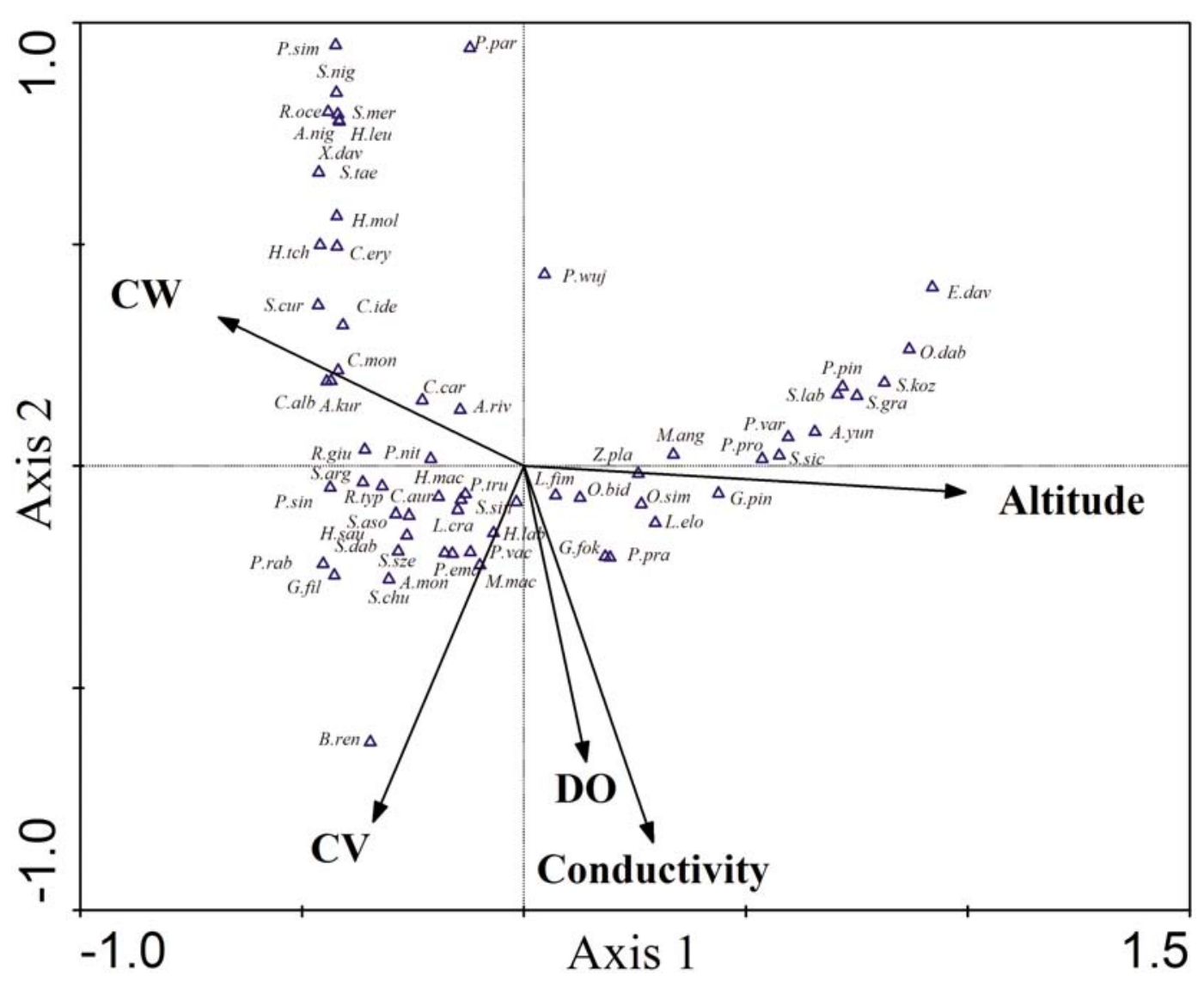

Figure 3

Species distribution in relation to significant environmental variables (see Table II for species code).

\section{Figure 3}

Distribution des espèces en relation avec les variables environnementales significatives (voir tableau II pour les codes d'espèce).

This zone can thus be considered as an important corridor for fish between the Chishui River and the Yangtze River.

\section{ACKNOWLEDGEMENTS}

We thank Zhiguo Miao, Haitao Zhao, Deqing Tan, Futie Zhang and Yongxiang Chen for field assistance; Shengguo Dan and Huanzhang Liu for aid in taxonomic classification; Xin Gao, Shaorong Yang, Xiaoming Jiang, Xiao Xi and two anonymous reviewers for constructive comments on earlier drafts. This study was funded by the Agriculture Ministry's Aquatic Wild Fauna and Flora Administrative Office ( $\mathrm{N}^{\circ}$ 071Z13).

\section{REFERENCES}

Araujo F.G., Pinto B.C.T. and Teixeira T.P., 2009. Longitudinal patterns of fish assemblages in a large tropical river in southeastern Brazil: evaluating environmental influences and some concepts in river ecology. Hydrobiologia, 618, 89-107.

Brown L.R., 2000. Fish communities and their associations with environmental variables, lower San Joaquin River drainage, California. Environ. Biol. Fishes, 57, 251-269.

Chen Y.Y., 1998. Fauna Sinica (Osteichthyes): Cypriniformes, II, Science Press, Beijing (in Chinese). 
Chu X.L., Zheng B.S. and Dai D.Y., 1999. Fauna Sinica (Osteichthyes): Siluriform, Science Press, Beijing (in Chinese).

Ding R.H., 1994. The Fishes of Sichuan, China, Sichuan Publishing House of Science and Technology, Chengdu (in Chinese).

Eaton J.G. and Scheller R.M., 1996. Effects of climate warming on fish thermal habitat in streams of the United States. Limnol. Oceanogr., 41, 1109-1115.

Edds D.R., 1993. Fish assemblage structure and environmental correlates in Nepal's Gandaki River. Copeia, 1, 48-60.

Feyrer F. and Healey M.P., 2003. Fish community structure and environmental correlates in the highly altered southern Sacramento-San Joaquin Delta. Environ. Biol. Fishes, 66, 123-132.

Fialho A.P., Oliveira L.G., Tejerina-Garro F.L. and de Mérona B., 2008. Fish-habitat relationship in a tropical river under anthropogenic influences. Hydrobiologia, 598, 315-324.

Fu C.Z., Wu J.H., Chen J.K., Wu Q.H. and Lei G.C., 2003. Freshwater fish biodiversity in the Yangtze River basin of China: patterns, threats and conservation. Biodivers. Conserv., 12, 1649-1685.

Gasith A. and Resh V.H., 1999. Streams in Mediterranean climate regions: abiotic influences and biotic responses to predictable seasonal events. Ann. Rev. Ecolog. Syst., 30, 51-81.

Godinho F.N., Ferreira M.T. and Santos J.M., 2000. Variation in fish community composition along an Iberian river basin from low to high discharge: relative contributions of environmental and temporal variables. Ecol. Freshwater Fish, 9, 22-29.

He Y.F., Wang J.W., Lek S., Cao W.X. and Lek A., 2011. Structure of endemic fish assemblages in the upper Yangtze River Basin. River Res. Appl., 27, 59-75.

Hocutt C.H. and Stauffer J.R., 1975. Influence of gradient on the distribution of fishes in Conowingo Creek, Maryland and Pennsylvania. Chesap. Sci., 16, 143-147.

Ibanez C., Oberdorff T., Teugels G., Mamononekene V., Lavoué S., Fermon Y., Paugy D. and Toham A.K., 2007. Fish assemblages structure and function along environmental gradients in rivers of Gabon (Africa). Ecol. Freshwater Fish, 16, 315-334

Jackson D.A., Peres-Neto P.R. and Olden J.D., 2001. What controls who is where in freshwater fish communities-the roles of biotic, abiotic, and spatial factors. Can. J. Fish. Aquat. Sci., 58, 157-170.

Karr J.R., 1981. Assessment of biotic integrity using fish communities. Fisheries, 6, 21-27.

Lammert M. and Allan J.D., 1999. Assessing biotic integrity of streams: effects of scale in measuring the influence of land use/cover and habitat structure on fish and macroinvertebrates. Environ. Manage., 23, 257-270.

Matthews W.J., 1998. Patterns in freshwater fish ecology, Chapman and Hall, Norwell.

Matthews W.J. and Hill L.G., 1979. Influence of physico-chemical factors on habitat selection by red shiners, Notropis lutrensis (Pisces: Cyprinidae). Copeia, 1, 70-81.

Oberdorff T., Pont D., Hugueny B. and Porcher J.P., 2002. Development and validation of a fish-based index for the assessment of 'river health' in France. Freshw. Biol., 47, 1720-1734.

Platts W.S., 1979. Relationships among stream order, fish populations, and aquatic geomorphology in an Idaho river drainage. Fisheries, 4, 5-9.

Poff N.L.R. and Allan J.D., 1995. Functional organization of stream fish assemblages in relation to hydrological variability. Ecology, 76, 606-627.

Shahnawaz A., Venkateshwarlu M., Somashekar D.S. and Santosh K., 2010. Fish diversity with relation to water quality of Bhadra River of Western Ghats (INDIA). Environ. Monitor. Assess., 161, 83-91.

Tejerina-Garro F.L., Fortin R. and Rodriguez M.A., 1998. Fish community structure in relation to environmental variation in floodplain lakes of the Araguaia River, Amazon Basin. Environ. Biol. Fishes, 51, 399-410.

Ter Braak C.J.F. and Smilauer P., 2002. CANOCO Reference Manual and CanoDraw for Windows User's Guide: Software for Canonical Community Ordination (version 4.5), Ithaca, NY, Microcomputer Power.

Wu J.M., Wang Q.Q., Liu F., Liu C.C., Zhang F.T. and Wang J.W., 2010. Fish Resources of early life in Chishui section of the Chishui River. Resources and Environment in the Yangtze Basin, 19, 1270-1276 (in Chinese).

Wu L., 1989. The Fishes of Guizhou Province, Guizhou People's Publishing House, Guiyang (in Chinese). Yue P.Q., 2000. Fauna Sinica (Osteichthyes): Cypriniformes, III, Science Press, Beijing (in Chinese). 